\title{
Effect of Peanut (Arachis Hypogaea L.) on Dyslipidemia in Young Adult
}

\author{
Hasina Akter ${ }^{1}$, Nasim Jahan ${ }^{2}$, Nayma Sultana ${ }^{3}$
}

\begin{abstract}
Background: Dyslipidemia is a major risk factor for cardiovascular disease. Lipid lowering drugs are available in modern medicine but prolong use of these drugs may produce some side effects. Peanut due to some of its active component can improve lipid profile. Objective: To observe the effects of peanut (Arachis hypogaea L.) on dyslipidemia in young adults. Methods: This prospective interventional study was carried out in the Department of Physiology, Sir Salimullah Medical College (SSMC), Dhaka between $1^{\text {st }}$ July 2013 and $30^{\text {th }}$ June 2014. For this purpose 30 dyslipidemic young adults of both sexes with aged 30 to 40 years were included in this study and they were selected from Out Patient Department of Medicine of Sir Salimullah Medical College and Mitford Hospital, Dhaka. They were studied three times i,e before supplementation with peanut (BSP), after 4 weeks supplementation with peanut (4 wks AP) and after 8 weeks supplementation with peanut ( 8 wks AP). For assessing lipid profile TAG, LDL-C, TC and HDL-C of all subjects were estimated by enzymatic method. The statistical analysis was done by using paired sample ' $t$ ' test as applicable. Results: In this study, the mean serum TAG, LDL-C and TC levels were significantly decreased after 8 weeks supplementation with peanut in comparison to those of after 4 weeks and before supplementation with peanut. However, these levels were also decreased after 4 weeks supplementation than those of before supplementation but it was significant only for TC $(p<0.05)$ and LDL-C $(p<0.001)$. Whereas, the mean serum HDL-C level was significantly $(\mathrm{p}<0.001)$ increased after 8 weeks supplementation when compared to those of after 4 weeks and before supplementation of peanut. Conclusion: The present study revealed that, peanut (Arachis hypogaea L.) has effect on improvement of lipid profile by lowering serum TAG, LDL-C, TC levels and by increasing serum HDL-C level. This lipid lowering effects of peanut may be due to its high $\mathrm{Mg}^{+2}$ content and other active components of peanut.
\end{abstract}

Key words: Dyslipidemia, peanut, lipid profile.

J Bangladesh Soc Physiol. 2015, June; 10(1): 11-16 For Authors Affiliation, see end of text.

http://www.banglajol.info/index.php/JBSP

\section{Introduction}

D yslipidemia is a disorder of lipoprotein metabolism, which includes increase blood concentrations of total cholesterol (TC), low density lipoprotein cholesterol (LDL-C), triacylglycerol (TAG) and decrease in high-density lipoprotein cholesterol (HDL-C) and is directly associated with the

Received April 2014; $\quad$ Accepted November 2014 development of cardiovascular diseases (CVD) ${ }^{1}$. Cardiovascular disease (CVD) includes hypertension, coronary heart disease, angina, myocardial infarction, heart failure etc ${ }^{2}$. According to World Health Organization (WHO), about 17.5 million people died from CVDs in 2005, representing $30 \%$ of global deaths and over $80 \%$ deaths take place in low and middle socio-economic countries

J Bangladesh Soc Physiol. 2015, June; 10(1): 11-16 
like Bangladesh ${ }^{3}$. Due to rapid urbanization the coronary heart disease in middle aged and young group is appearing at increasing level in Bangladesh ${ }^{4}$. However, recently a study showed a significant relationship of dyslipidemia with age, sedentary occupation, body mass index (BMI), diet and smoking among some young adult Bangladeshi subjects aged 18 and above ${ }^{5}$. Again, dyslipidemia and obesity two important risk factors of CVDs were found in some employers of Bangladesh secretariat who had sedentary life style ${ }^{6}$. Another study in Bangladesh revealed that 27.93\%, 21.08\% and $13.41 \%$ stroke patients with lipid disorder had high cholesterol, low density lipoprotein (LDL), and triglyceride (TG) levels respectively and $42.67 \%$ patients had low HDL level. Furthermore, the levels of serum TC, LDL-C and TG were found higher among some educated and high income urban population of Rajshahi city ${ }^{7}$.

Arachis hypogaea L. known as peanut belongs to the family of fabaceae has been valued for its high nutritional content throughout the world for many years ${ }^{8}$. Peanut is a nutrient dense food rich in plant protein (10\%-25\%) and fat (50\%$75 \%)^{9}$. Peanut is rich in unsaturated fatty acid predominantly monounsaturated fatty acid (MUFA) and polyunsaturated fatty acids (PUFA) and low saturated fatty acids and also contain several non-fat bioactive constituents such as plant protein ${ }^{10}$, dietary fiber ${ }^{11}$, non-starch polysaccharides ${ }^{12}$, arginine ${ }^{13}$, vitamins (e.g., folic acid, niacin, tocopherol and pyridoxine), minerals (e.g., magnesium, copper, calcium and potassium) and many other bioactive constituents such as phytosterols ${ }^{14}$, flavonoids and resveratrol ${ }^{13}$. However, peanut causes food allergy approximately $1 \%$ in general population 15 and mainly affects young children ${ }^{16}$. It has been observed that, consuming two ounce of nuts daily as replacement for carbohydrates can reduce blood glucose and LDL-C levels in people with diabetes ${ }^{17}$. Some other researchers showed that, daily 56 g peanut consumption may improve blood HDL-cholesterol levels ${ }^{18}$.

Due to some active components peanut has highly medicinal value and it is cultivated in many places of Bangladesh such as Kurigram, Rangpur,
Mymensingh, Joydebpur etc. It is relatively cheap and available in relation to other nuts. Therefore, the present study has been designed to observe the effect of peanut on dyslipidemia in young adults. It is also expected that the result of this study would make peanut accectable among the people as a rich source of nutrition with medicinal value for the prevention and treatment of dyslipidemia.

\section{Methods}

This prospective interventional study was carried out in the Department of Physiology, SSMC, Dhaka between $1^{\text {st }}$ July 2013 and 30th June 2014. The study protocol was approved by the Institutional Ethics Committee (IEC) of SSMC. Thirty young adult subjects of both sexes, aged 30-40 years, diagnosed case of dyslipidemia were included by purposive sampling from the out Patient Department of Medicine in Sir Salimullah Medical College and Mitford Hospital, Dhaka. They were studied three times i,e before supplementation with peanut (BSP), after 4 weeks supplementation with peanut (4 wks AP) and after 8 weeks supplementation with peanut ( 8 wks AP). Subjects having diabetes mellitus, hypertension, heart disease, kidney disease, liver disease, thyroid disease, infectious disease etc were excluded from the study. Informed written consent was taken from each subject. Subsequently, a detail family and medical histories were taken to rule out any chronic and known illness which runs in the family and also physical activity status were recorded. All the subjects were supplemented with peanut at about $20 \%$ of their daily calorie intake. Three days dietary history of each subjects was taken for calculating the amount of peanut that was supplemented to each of the subjects (Table 1).

With all aseptic precautions, five (5) ml of venous blood was drawn from median cubital vein by sterile disposable syringe. To assess their lipid profile serum level of TAG, LDL-C, HDL-C and TC of all subjects were estimated by enzymatic method in the laboratory of Department of Physiology, Sir Salimullah Medical College, Dhaka. Data were analyzed by Paired sample ' $\mathrm{t}$ ' test as applicable for statistical analysis. P value $<0.05$ was taken as level of significance. 
Table 1: Diet history (Kcal/day) for calculating amount of peanut consumption/ day of one of the study subjects

\begin{tabular}{|c|c|c|c|c|c|}
\hline \multicolumn{2}{|c|}{ Day-1 } & \multicolumn{2}{|c|}{ Day-2 } & \multicolumn{2}{|l|}{ Day-3 } \\
\hline Parata-3 pieces & $120 \times 3=360$ & Parata-3 piece & $120 \times 3=360$ & Parata-3 pieces & $120 \times 3=360$ \\
\hline Fried egg-1 piece & 100 & Fried egg-1 piece & 100 & Vagi/dal-1 cup & 100 \\
\hline Milk tea-1 cup & 45 & Singara-1 piece & 80 & Milk tea-1 cup & 45 \\
\hline Puri-2 pieces & $55 \times 2=110$ & Milk tea-1 cup & 45 & & \\
\hline Rice-3 cup & $120 \times 3=360$ & Rice-3 cup & $120 \times 3=360$ & Chicken fried & $190 \times 2.5=$ \\
\hline Dal-1 cup & 90 & Dal-1 cup & 90 & rice-2.5 cup & 475 \\
\hline Vegetables-1 cup & 60 & Vegetables-1 cup & 60 & Cold drinks-1glass & 140 \\
\hline Chicken-1 piece & 120 & Alu vagi-1 cup & 100 & Curd-1 cup & 100 \\
\hline Soup-1 cup & 60 & Milk tea-1 cup & 45 & Sweets- 1 piece & 150 \\
\hline Rice-2 cup & $120 \times 2=240$ & Rice-2 cup & $120 \times 2=240$ & Rice-2 cup & $120 \times 2=240$ \\
\hline Vegetables-1 cup & 60 & Dal-1 cup & 90 & Vegetables-1 & 100 \\
\hline \multirow[t]{2}{*}{ Dal-1 cup } & 90 & Vegetables-1 & 60 & cup & \\
\hline & & cup & & Fish-1 piece & 150 \\
\hline Total calorie/day & 1695 & & 1630 & & 1860 \\
\hline
\end{tabular}

Mean calorie intake/day $(\mathrm{Kcal})=1728.33$

$20 \%$ of mean calorie intake/day $(\mathrm{Kcal})=345.67$

149 Kcal energy will get from 28 g of peanut ${ }^{9}$

345.67 Kcal energy will get from 65 g of peanut

\section{Results}

In this study, BMI was significantly decreased in 8 wks AP in comparison to that of BSP. Again, this level was almost similar in BSP and 4 wks AP bu the difference was not statistically significant.

The mean W:H ratio level was almost similar and the differences was not statistically significant after 4 weeks and 8 weeks supplementation of peanut (Table II).

In this study, serum level of TAG, LDL-C and TC were significantly decreased in 8 wks AP in comparison to those of 4 wks AP and BSP. Serum HDL-C level was significantly increased in 8 wks AP in comparison to that of 4 wks AP and BSP (Table III).

Table II: Body mass index (BMI) and waist-hip circumference ratio (W:H) in different phases $(\mathrm{n}=30)$

\begin{tabular}{lccc}
\hline Parameters & BSP & 4 wks AP & 8 wks AP \\
\hline $\mathbf{B M I}\left(\mathbf{K g} / \mathbf{m}^{2}\right)$ & $27.92 \pm 1.32$ & $27.68 \pm 1.23$ & $27.08 \pm 1.22 *$ \\
$\mathbf{W : H}$ & $0.92 \pm 0.02$ & $0.92 \pm 0.02$ & $0.92 \pm 0.02$ \\
\hline
\end{tabular}

Data are expressed as mean \pm SD. For statistical analysis, paired-sample ' $t$ ' test within the phase were performed. $\left({ }^{*} \mathrm{p}<0.05\right.$ BSP versus 8 wks AP). BSP= Before supplementation of peanut (on day-1). 4 wks AP= After 4 weeks supplementation of peanut (on $28^{\text {th }}$ day). 8 wks AP= After 8 weeks supplementation of peanut (on $56^{\text {th }}$ day).

J Bangladesh Soc Physiol. 2015, June; 10(1): 11-16 
Table II1: Serum TAG, LDL-C, HDL-C and TC levels in different phases ( $\mathrm{n}=30$ )

\begin{tabular}{lccc}
\hline Parameters (mg/dl) & BSP & 4 wks AP & 8 wks AP \\
\hline Serum TAG & $246.1 \pm 9.7$ & $241.1 \pm 9.7$ & $234.5 \pm 9.8^{* * *,,^{-"}}$ \\
Serum LDL-C & $203.9 \pm 6.9$ & $197.0 \pm 6.9^{\S \S}$ & $188.4 \pm 6.9^{* * *}, \cdot \cdots$ \\
Serum HDL-C & $36.4 \pm 3.5$ & $38.2 \pm 3.3$ & $40.7 \pm 3.3^{* * *, \cdot}$ \\
Serum TC & $280.3 \pm 11.4$ & $271.17 \pm 11.8^{\S}$ & $262.17 \pm 11.5^{* * *, \cdot}$ \\
\hline
\end{tabular}

Data are expressed as mean \pm SD. For statistical analysis, paired-sample ' $t$ ' test within the phase were performed. $\left({ }^{\S} \mathrm{p}<0.05 ;{ }^{\S} \mathrm{p}<0.01\right.$ BSP versus 4 wks AP); $\left({ }^{* * *} \mathrm{p}<0.001\right.$ BSP versus 8 wks AP) and $(" \mathrm{p}<0.05$; $\cdots \mathrm{p}<0.0014$ wks AP versus 8 wks AP). BSP= Before supplementation of peanut (on day-1). 4 wks AP= After 4 weeks supplementation of peanut (on $28^{\text {th }}$ day). 8 wks AP $=$ After 8 weeks supplementation of peanut (on $56^{\text {th }}$ day).

\section{Discussion}

In this study, serum level of TAG, LDL-C and TC were significantly decreased and serum HDL-C level was significantly increased in 8 wks AP in comparison to that of 4 wks AP and BSP. This finding is consistent with that of some other investigators $18,19,20$. In contrast, some other researchers did not find any significant change of serum TC and TAG levels in hypercholesterolemic subjects by dietary supplementation with peanut for 4 weeks This discrepancy may be due to their short duration of study period 18,21 .

It has been suggested that circulating level of excess cholesterol causes development of atheroma within intima layer of the arterial wall. Ulceration or disruption of the atheroma causes thrombotic occlusion or embolism which impairs blood flow to vital organ such as brain, heart and other organs ${ }^{2}$. However, oleic acid which is the predominant mono-unsaturated fatty acid (MUFA) in peanut ${ }^{22}$, exerts anti-hypertensive effects ${ }^{23}$, prevents LDL oxidation ${ }^{24}$, reduces platelet aggregation ${ }^{25}$ and enhances fibrinolysis, thereby reduces the risk of cardiovascular diseases 26,27 .

The flavonoids and phytosterols in peanut can inhibit dietary cholesterol absorption thereby decreasing blood cholesterol levels ${ }^{28,29}$. Again, Resveratrol, a polyphenol phytoalexin of peanuts provides protection from atherosclerosis by decreasing serum total cholesterol (TC) and triglyceride (TG) levels and increasing serum HDL level ${ }^{30}$. In addition, fiber of peanut reduces total and LDL-cholesterol level and reduces insulin resistance ${ }^{12}$. Nut is one of the best dietary sources of vitamin $\mathrm{E}$ (á-tocopherol) and is associated with reduced risk of coronary heart disease (CHD) by inhibition of LDL oxidation ${ }^{10}$.

Regular consumption in small amount of peanut contributes daily requirement for $\mathrm{Mg}^{+2} 10$. Some studies confirm that, dietary $\mathrm{Mg}^{+2}$ decreases serum cholesterol and triglycerides levels ${ }^{31}$. Low serum $\mathrm{Mg}^{+2}$ concentrations can reduce lipoprotein lipase and lecithincholesterol acyltransferase (LCAT) activity which results in hyperlipidemia ${ }^{32}$.

In the present study, improvement of lipid profile is found in young adult as evidenced by gradual decreased levels of serum TC, LDL-C, TAG and gradual increased level of HDL-C after 4 weeks and 8 weeks supplementation of peanut. This lipid lowering effect of peanut may be due to its higher content of $\mathrm{Mg}^{+2}$ and other active component.

\section{Conclusion}

From this study, it can be concluded that, peanut (Arachis hypogoea L.) has got significant effect on improvement of lipid profile with lowering 
serum level of TAG, LDL-C, TC and increasing serum HDL-C level. This lipid lowering effects of peanut may be due to its high content of $\mathrm{Mg}^{+2}$ and other active components of peanut.

\section{Conflict of interest : None}

\section{Author Affiliation}

1. * Hasina Akter, M.Phil, Department of Physiology, Sir Salimullah Medical College, Mitford, Dhaka. Email:hasinabd27@gmail.com

2. Nasim Jahan, Professor \& Head, Department of Physiology, Sir Salimullah Medical College, Mitford, Dhaka.E-mail: prof.dr.nasimjahan@gmail.com

3. Nayma Sultana, Professor, Department of Physiology, Sir Salimullah Medical College, Mitford, Dhaka. E-mail: nayma_sultana@yahoo.com

*For correspondence

\section{Reference}

1. Field MJ, Burnett L, Sullivan DR, Stewart P. Clinical biochemistery and metabolism. In: Walker BR, Colledge NR, Ralston SH, Penman ID. (eds.). Davidson's Principle and Practice of Medicine. 22 ${ }^{\text {th }}$ ed. China. Churchil Livingstone Elsevier. 2014; 447-458.

2. Newby DE, Grubb NR, Bradbary A. Cardiovascular disease. In: Walker BR, Colledge NR, Ralston SH, Penman ID. (eds.). Davidson's Principle and Practice of Medicine. 22 $2^{\text {th }}$ ed. China. Churchil Livingstone Elsevier. 2014; 575-589.

3. World Health Organization. Global atlas on cardiovascular disease prevention and control. 2011 March; 11-14 .

4. Khandakar MR, Ahsan R, Haque MJ. Socio-economic Status and Risk of Coronary Heart Disease (CHD) in a Northern Urban Community of Bangladesh. Dinajpur Med Col J. 2010; 3(2): 67-75.

5. Nadira I, Zillur R, Sadia C, Lazina A, Sonia R, Mohammad A. Prevalence of dyslipidemia and associated factors among the sub-urban bangladeshi population. Univ Heart J. 2012; 8(1): 15-19.

6. Alam MB, Ahasan $\mathrm{HN}$, Islam Z, Islam $\mathrm{N}$, Mohammed FR, Nur Z, Mahbub S, Faiz A. Pattern of lipid profile and obesity among secretariat employeers of Bangladesh. J Medicine. 2009; 10(1): 3-6.

7. Badiuzzaman M, Mohammed FR, Chowdhury FR, Bari MS, Alam MB, Ahasan HN. Prevalence of modifiable risk factors among stroke patients in a tertiary care hospital in Dhaka. J Medicine. 2009; 10(1): 18-21.

J Bangladesh Soc Physiol. 2015, June; 10(1): 11-16
8. Higgs J. The beneficial of peanuts in the diet- part 2. Nutrition \& Food science. 2003; 33(2): 56-64.

9. Ros E, Mataix J. Fatty acid composition of nuts: implications for cardiovascular health. Br J Nutr. 2006; 96(2): 29-35.

10. Kris-Etherton P, Pearson TA, Van Y, Hargrove RL, Moriarty K, Fishell V, Etherton TD. High monounsaturated fatty acid diets lower both plasma cholesterol and triacylglycerol concentrations. Am J Clin Nutr. 1999; 70: 1009-15.

11. Salas-Salvad J, Bullo M, Perez-Heras H, Ros E. Dietary fiber, nuts and cardiovascular disease. $\mathrm{Br} \mathrm{J}$ Nutr. 2006; 96(2): 46-51.

12. Kirkmeyer S, Mattes RD. Effects of food attributes in hunger and food intake. Int J Obes. 2000; 24: 1167-75.

13. Higgs J. The beneficial role of peanuts in the diet an update and rethink Peanuts and their role in CHD. Nutrition \& Food Science. 2002; 32(6): 214-18.

14. Segura R, Javierre C, Lizarraga MA, Ros E. Other relevant components of nuts, phytosterols, folate and minerals. Br J Nutr. 2006; 96(2): 36-44.

15. Crespo JF, James JM, Fernandez C, Rodriguez J. Food allergy: nuts and tree nuts. Br J Nutr. 2006; 96(2): S95-S102.

16. Zuidmeer L, Goldhahn K, Rona RJ, Gislason D, Madsen C, Summers C, Sodergren E, Dahlstrom J, Lindner T, Sigurdardottir ST, Bride DM, Keil T. The prevalence of plant food allergies: a systematic review. J Allergy Clin Immunol. 2008; 121(5): 1210-18.

17. Jenkins DJA, Kendall CWC, Banach MS, Srichaikul K, Vidgen E, Mitchell S, Parker T, Nishi S, Bashyam B, Souza RD, Ireland C, Josse RG. Nutsasa replacement for carbohydrates in the diabetic diet. Diabetes Care. 2011; 34: 1706-11.

18. Kiernan FM, Lokko P, Kuevi A, Sales RG, Costa MB, Bressan J, Alfenas CG, Mattes RD. Effects of peanut processing on body weight and fasting plasma lipids. Br J Nutr. 2010; 104: 418-26.

19. Jones JB, Provost M, Keaver L, Breen C, Maryjon L, Richard DM. A randomized trial on the effects of flavorings on the health benefits of daily peanut consumption. Am J Clin Nutr. 2013; 113: 1-7.

20. Mercanlýgil SM, Arslan P, Alasalvar C, Okut1 E, Akgu E, Pýnar A, Geyik PO, Tokgozoglu L, Shahidi F. Effects of hazelnut-enriched diet on plasma cholesterol and lipoprotein profiles in hypercholesterolemic adult men. Eur J Clin Nutr. 2007; 61: 212-220. 
21. Nouran MG, Kimiagar M, Abadi A, Mirzazadeh M, Harrison G. Peanut consumption and cardiovascular risk. PHN. 2009; 13(10): 1581-86.

22. Sales RL, Coelho SB, Costa NMB, Bressan J, Iyer S, Boateng LA, Lokko P, Mattes RD. The effects of peanut oil on lipid profile of normolipidemic adults: a three country collaborative study. The Journal of Applied Research. 2008; 8(3): 216-225.

23. Teres S, Barcelo-Coblijn G, Benet M, Alvarez R, Bressani R, Halver JE, Escriba PV. Oleic acid content is responsible for the reduction in blood pressure induced by olive oil. PNAS. 2008; 105(37): 13811-16.

24. Mata P, Alonso R, Lopez-Farre A, Ordovas JM, Lahoz C, Garces C, Caramelo C, Codoceo R, Blazquez E, Oya M. Effect of dietary fat saturation on LDL oxidation and monocyte adhesion to human endothelial cells in vitro. Arterioscler Thromb Vasc Biol. 1996; 16(11): 1347-55.

25. Sirtori CR, Tremoli E, Gatti E, Montanari G, Sirtori M, Colli S, Gianfranceschi G, Maderna P, Dentne CZ, Testolin G, Galli C. (1986) Controlled evaluation of fat intake in the Mediterranean diet: comparative activities of olive oil and corn oil on plasma lipids and platelets in high-risk patients. Am J Clin Nutr. 1986; 44: 635-42.

26. Lopez-Segura F, Velasco J, Lopez-Miranda P, Castro R, Lopez-Pedrera A, Blanco J, Jimenez-Pereperez A, Torres J, Trujillo JM, Ordovas F, Pérez-Jiménez.
Monounsaturated fatty acid-enriched diet decreases plasma plasminogen activator inhibitor type -1 . Arterioscler Thromb Vasc Biol. 1995; 16: 82-88.

27. Perez-Jimenez F, Lopez-Miranda J, Mata P. Protective effect of dietary monounsaturated fat on arteriosclerosis: beyond cholesterol. Atherosclerosis. 2002; 163(2): 385-98.

28. Hu FB, Stampfer MJ, Manson JE, Rimm EB, Colditz GA, Rosner BA, Speizer FE, Hennekens CH, Willett WC. Frequent nut consumption and risk of coronary heart disease in women prospective cohort study. BMJ. 1998; 317(14): 1341-45.

29. Awad AB, Chan KC, Downie AC, Fink CS. Peanuts as a source of â-sitosterol, a sterol with anticancer properties. Nutr and Cancer. 2000; 36(2): 238-41.

30. Zhu L, Luo X, Jin Z. Effect of Resveratrol on serum and liver lipid profile and antioxidant activity in hyperlipidemia rats. Asian-Aust J Anim Sci. 2008; 21(6): 890 - 95.

31. Altura BT, Brust M, Bloomt S, Barbour RL, Stempak JG, Altura BM. Magnesium dietary intake modulates blood lipid levels and atherogenesis. Proc Natl. Acad. Sci. 1990; 87: 1840-44.

32. Gueux E, Rayssiguier Y, Piot M, Alcindor A. Reduction of plasma Lecithin Cholesterol Acyl transferase Activity by Acute Magnesium Deficiency in the Rat. J Nutr. 1984; 114: 1479-83. 